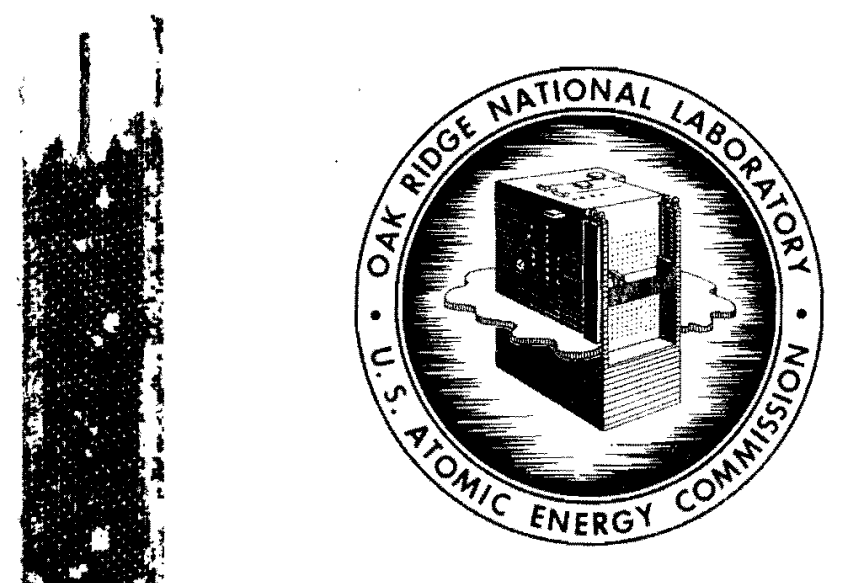

OAK RIDGE NATHAAT LABORATORY "

operated by

UNION CARBIDE CORPORATION

for the

U.S. ATOMIC ENERGY COMMISSION

ORNL- TM-178
24

\title{
A STUDY OF THE SHIELD OF THE UNIVERSITY OF ILLINOIS \\ TRIGA MARK II RESEARCH REACTOR
}

T. V. BLOSSER

R. M. FREESTONE, Jr.

J. M. MILLER

\section{NOTICE}

The information is not to be abstracted, reprinted or otherwise given public dissemination without the approval of the ORNL patent branch Legal and Information Control Department. 


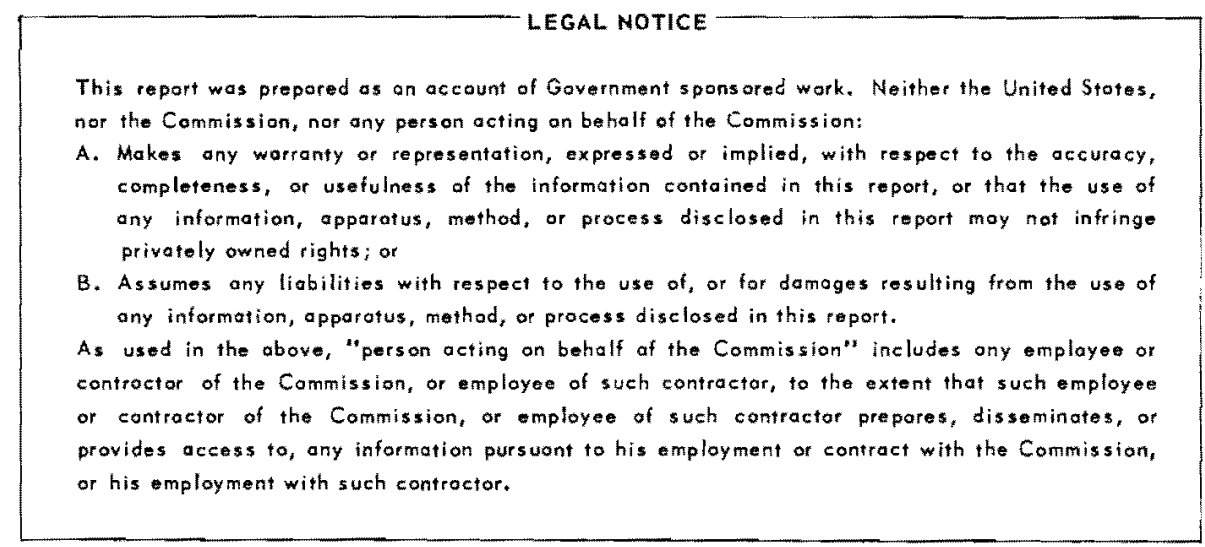


ORNL-TM-178

Contract No. W-7405-eng-26

Neutron Physics Division

A STUDY OF THE SHIELD OF THE UNIVERSTTY OF ILLTNOIS

TRIGA MARK II RESEARCH REACTOR

T. V. Blosser, R. M. Freestone, Ir., and

J. M. Miller

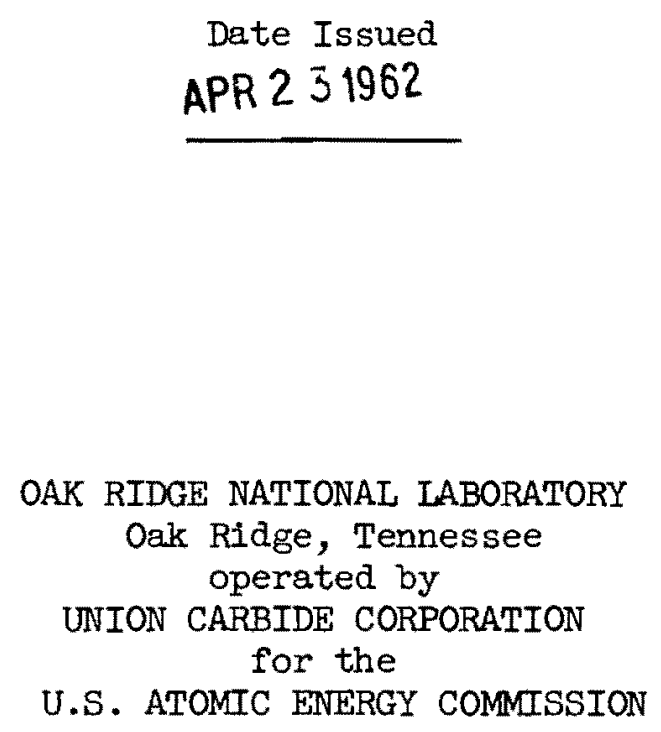




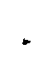

. 


\begin{abstract}
Detailed measurements have been made of the fast-neutron and gammaray dose rates and the thermal-neutron fluxes existing at the surfaces of the biological shield of the University of Illinois TRIGA Mark II Research Reactor. Dose rates and fluxes were found to be extremely low. A comparison was made by means of threshold foil techniques between the fast-neutron flux in a beam hole of the reactor during steady-state operation at $1 \mathrm{~kW}$ and during a nominal $250 \mathrm{MW}, 30 \mathrm{msec}$ pulse produced by rapid insertion of $\sim$ two dollars of excess reactivity. The flux over the duration of the pulse was approximately four times that for steady-state operation for $1 \mathrm{hr}$ at $1 \mathrm{kw}$. Fast-neutron dose rates and thermal-neutron f'luxes were measured at each of the four beam ports of the reactor at operating powers of zero, one and five watts. Some gamna-ray dose rate data was also obtained at zero and 1 watt. An appendix briefly describes the threshold foil technique used.
\end{abstract}


TABLE OF CONTENTS

Page No.

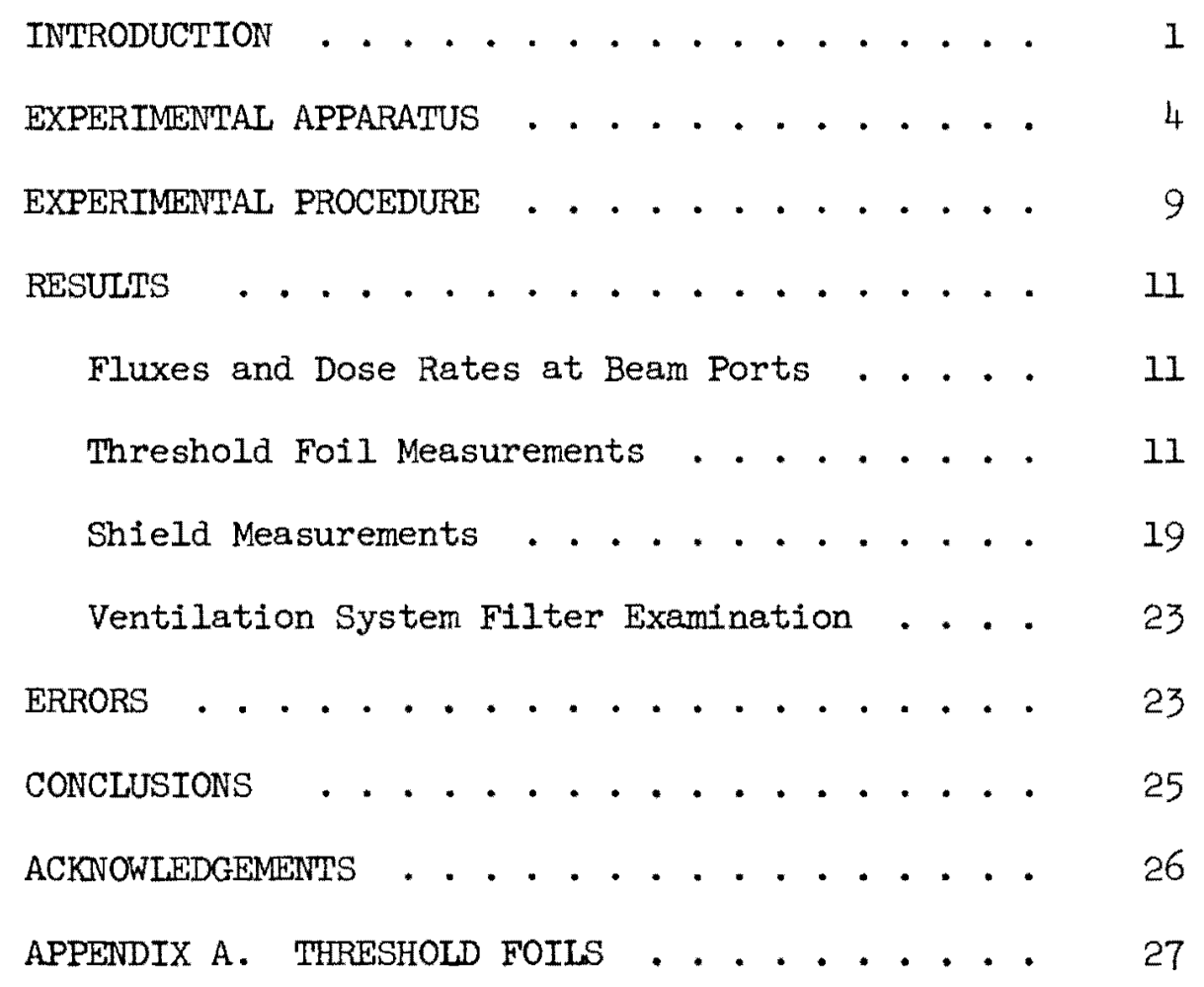




\section{A STUDY OF THE SHIELD OF THE UNIVERSITY OF ILLINOIS}

TRIGA MARK II RESEARCH REACTOR

T. V. Blosser, R. M. Freestone, Jr., and J. M. Miller

\section{INTRODUCTION}

The Division of Compliance of the U. S. Atomic Energy Commission has recently authorized a study of the shields of a number of typlcal research, experimental, and electric-power-producing nuclear reactors. The measurements are being made by the Neutron Physics Division of Oak Ridge National Laboratory, utilizing a mobile, van-contained radiation detection laboratory originally designed for measurement of extremely low-level radiation leakage expected from the shield of the N.S. SAVANNAH. The first shield to be examined in this program was that of the TRIGA Mark II research reactor operated by the University of Illinois as the central feature of its graduate program in nuclear engineering. ${ }^{1}$ The reactor is located in the northeast section of the University campus at Urbana, Illinois, in a specially bullt concrete structure. A photograph of the reactor facility is shown as Fig. 1, and a photograph of the reactor itself in Fig. 2. The TRIGA Mark II is a graphite-reflected water-cooled tank-type reactor, with a right-cylindrical core composed of cylindrical fuel-moderator rods of a mixture of uranium and zirconiumhydride contained in a 6-1/2-ft-dia tank of demineralized water. The normal level of water is 16 feet above the core, and cooling is by natural

1. TRIGA - Training-Research-Isotope Production-General Atomic: a reactor designed and built by the General Atomic Division of the General Dymamics Corporation. 


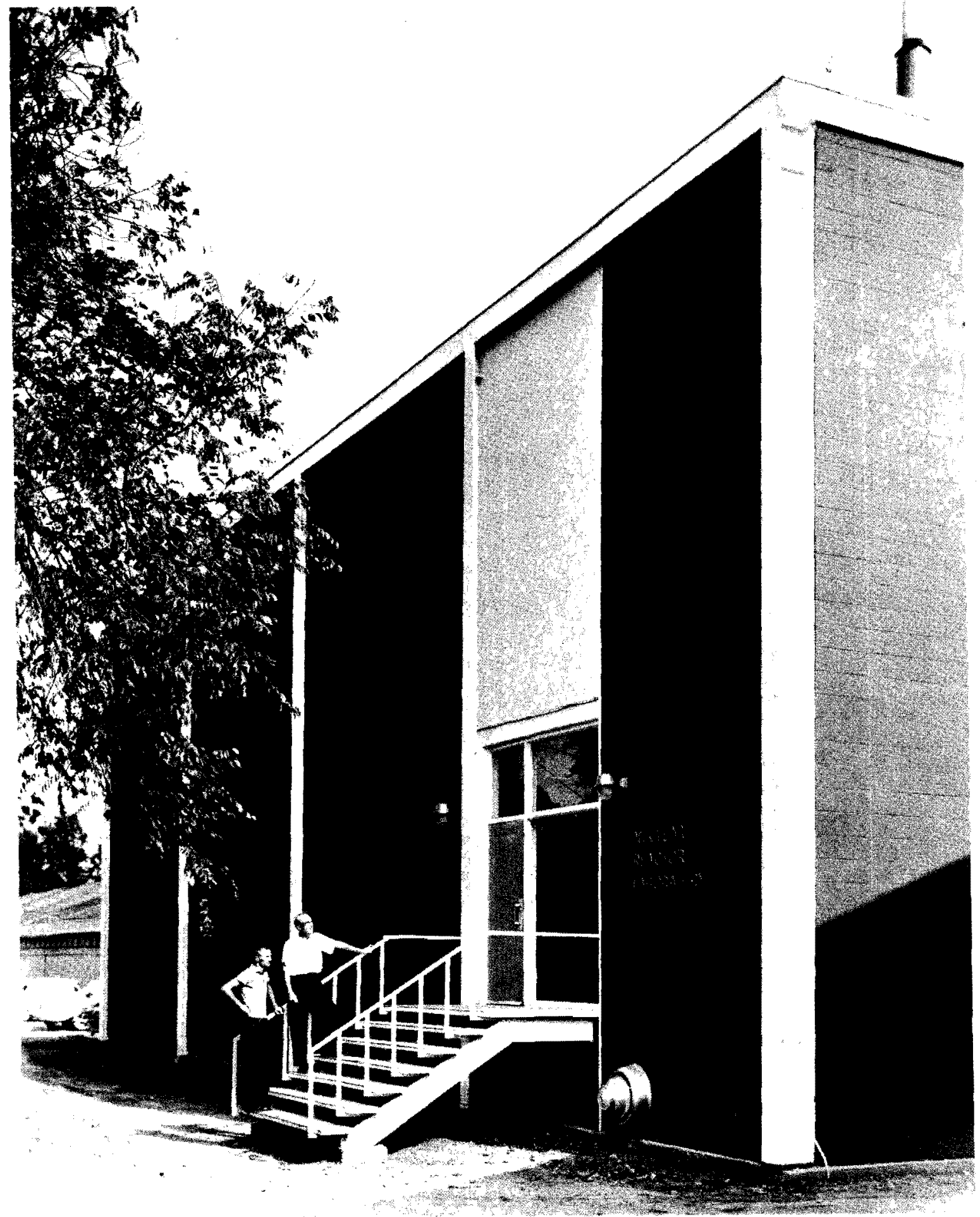

Fig. 1. The University of Illinois Nuclear Research Laboratory. This and the following two photographs were furnished through the courtesy of the University. 


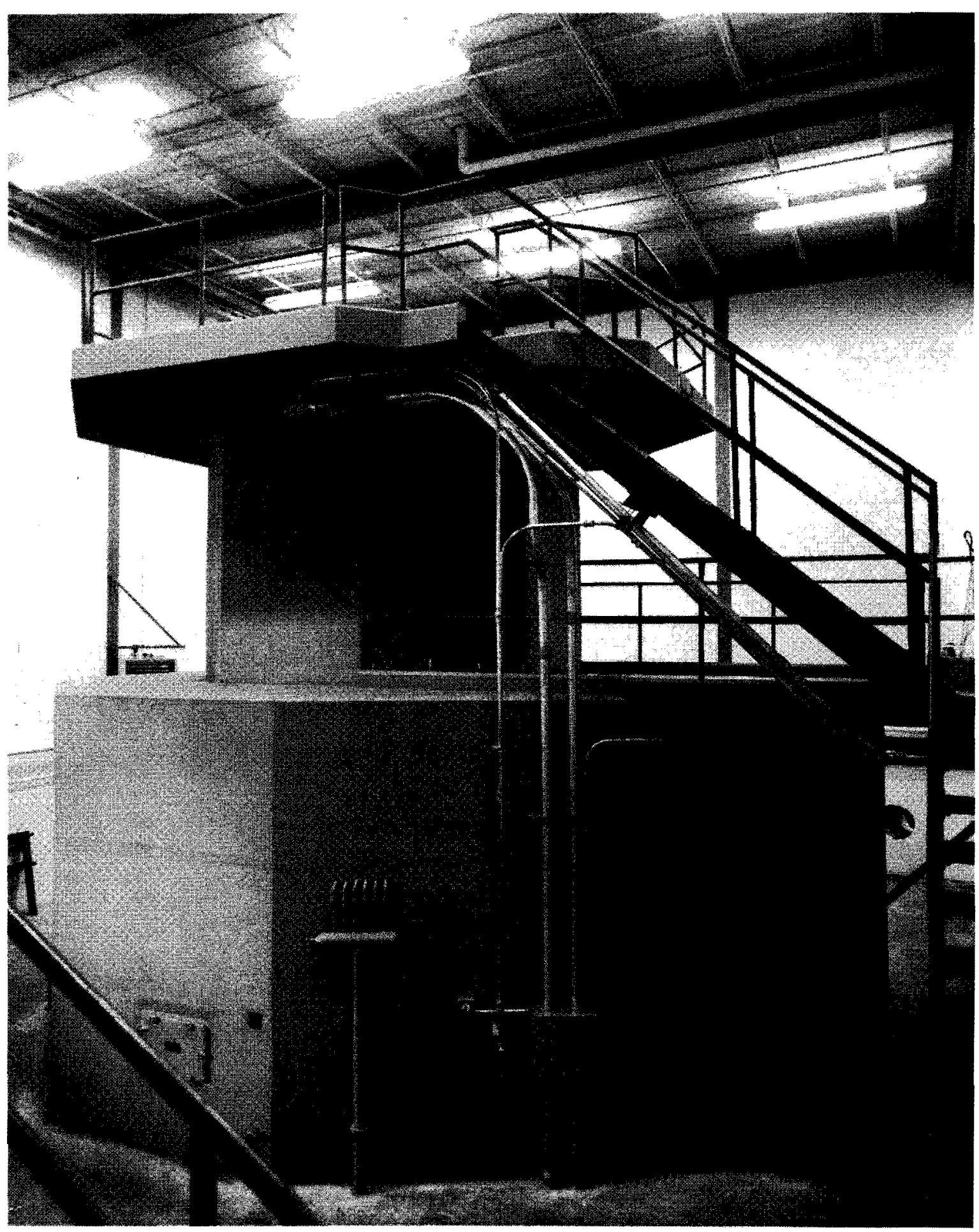

Fig. 2. The University of Illinois TRIGA Mark II Reactor. In this view the camera is looking northeast. The west beam hole is visible at the lower left. 
convection in this water. The shield surrounding the tank is magnetite concrete, 7-1/2-ft thick for a 12-ft base height (in the core region) and 3-1/2-ft thick for the upper 10 feet. Four 6-in.-dia beam tubes pierce this shield, glving access to the core at various angles. Three of these tubes can be seen in Fig. 3, a photograph taken during construction. The iron shadow shields surrounding these tubes should be noted, since the leakage measurements reported below may possibly be affected by them. In addition to the beam tubes, a 4-ft-square, 5-ft-long graphite thermal column pierces the northeast face of the shield, and an 8-ft by 9-ft bulk shielding pool, 12-ft deep, is located at the south side of the reactor. The graphite colum leading to this pool can be seen at the right side of the tank in Fig. 3 .

The nominal composition of the TRIGA Mark II fuel is 8 wt $\mathrm{U}$, enriched to 20 wt\% in $U^{235}, 91$ wt $\mathrm{zr}$, and 1 wt\% $\mathrm{H}$. Total $\mathrm{u}^{235}$ content of the present core is $2.1 \mathrm{~kg}$, and the average $f l u x$ within the core is estimated as $1.6 \times 10^{12} \mathrm{n} / \mathrm{cm}^{2} \cdot \mathrm{sec}$ at $100 \mathrm{kw}$ operation.

An interesting feature of this reactor lies in its capability of being pulsed. Although its steady-state power is $100 \mathrm{kw}$, excess reactivity of the order of two dollars can be abruptly inserted, triggering a burst of power as large as $250 \mathrm{Mw}$, with a $30 \mathrm{msec}$ half-power duration. Because of the large prompt negative coefflcient of reactivity inherent in the fuel element design, the pulse is self-terminating.

\section{EXPERTMENTAL APPARATUS}

The mobile radiation detection laboratory with wich this study was made is shown in Figs. 4 and 5 . Contained within the standard 5-ton vanette are seven shock-mounted racks of instrumentation, threshold foil counting equipment, a large paraffin-shielded container for calibration sources, and all supporting equipment, such as oscilloscope, tube checker, 


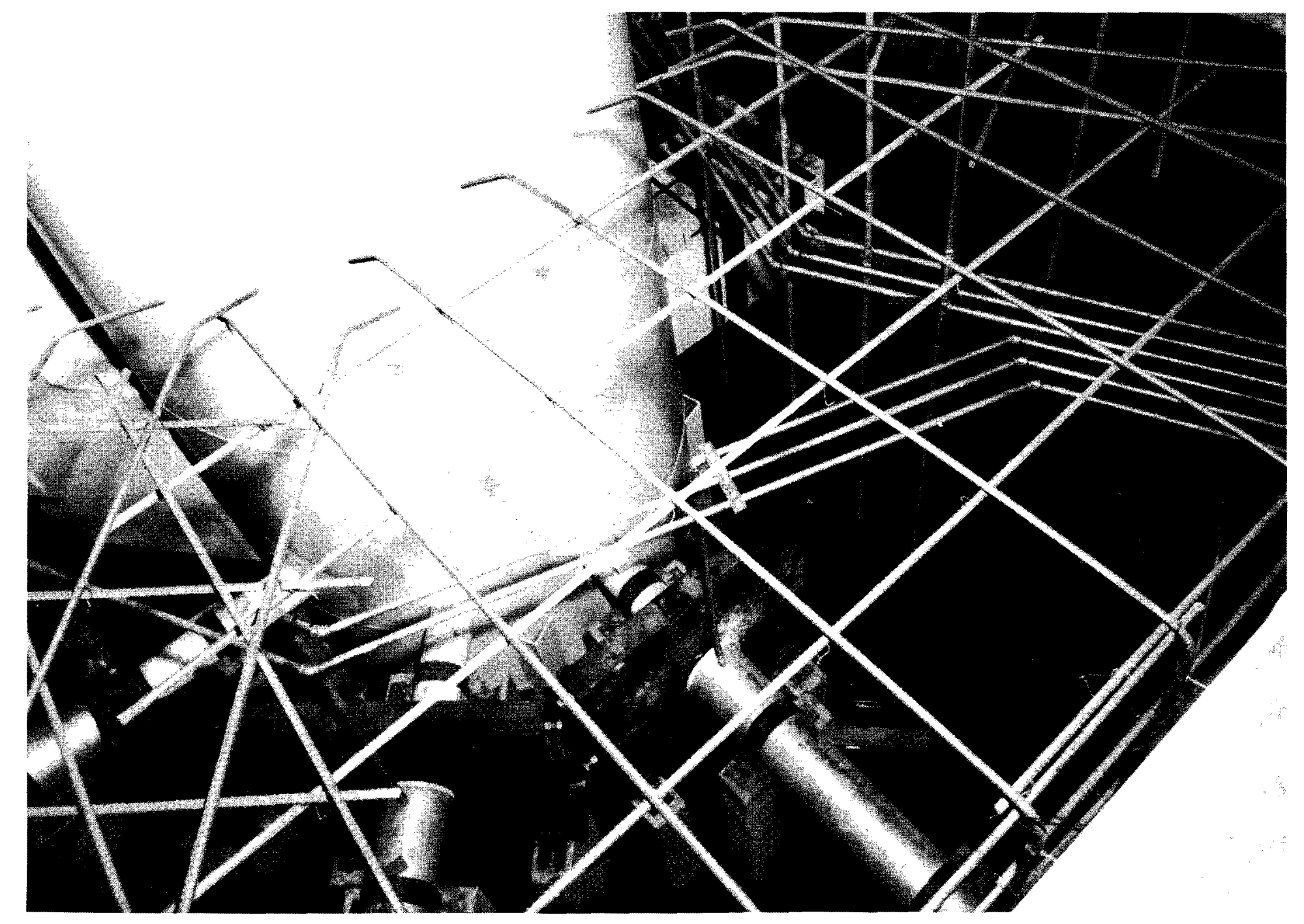

Fig. 3. View of the TRIGA Mark II Shield During Construction. The north, northwest, and west beam tubes are in the foreground. 


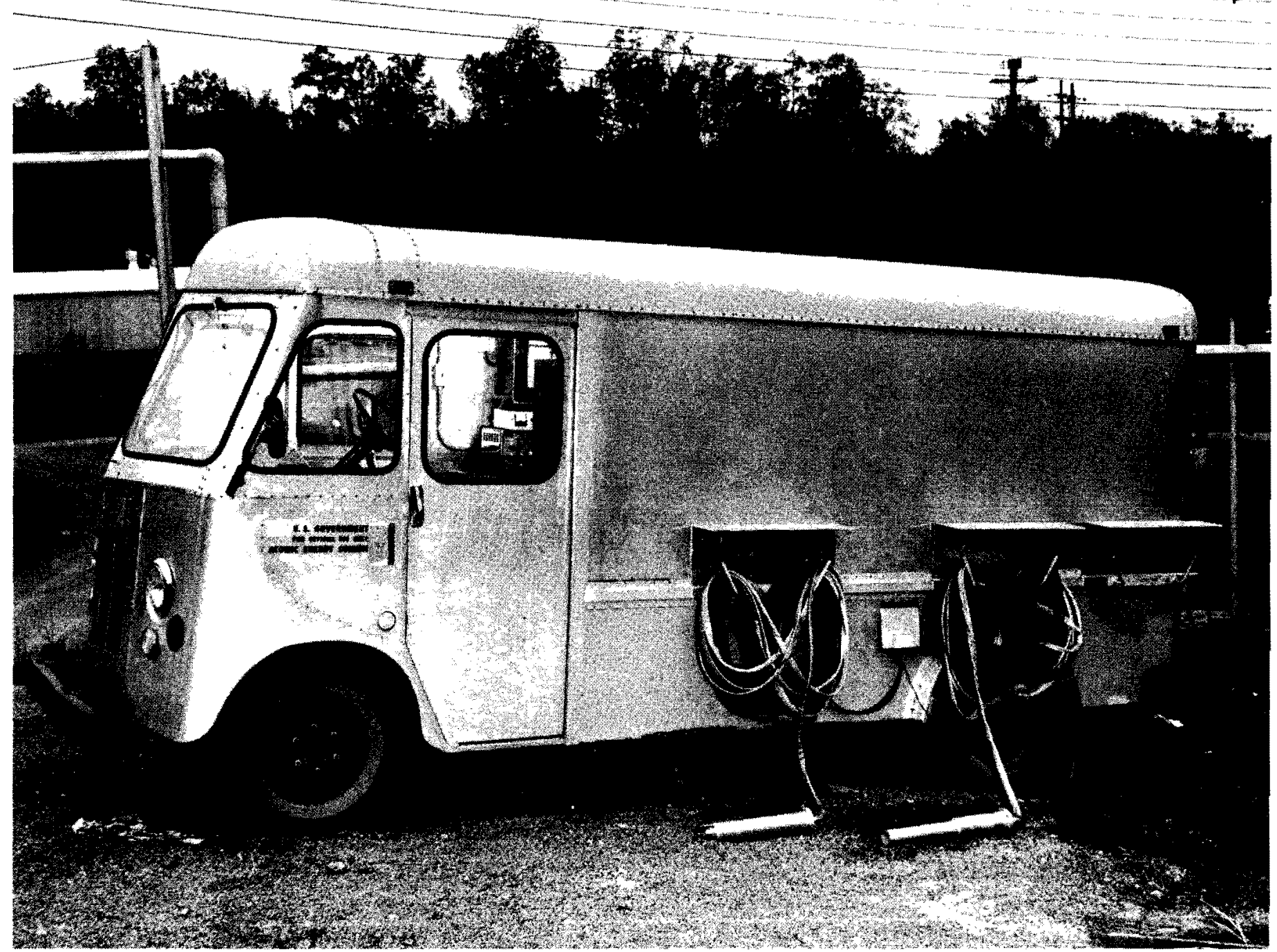

Fig. 4. The ORNL Mobile Radiation Detection Laboratory. 


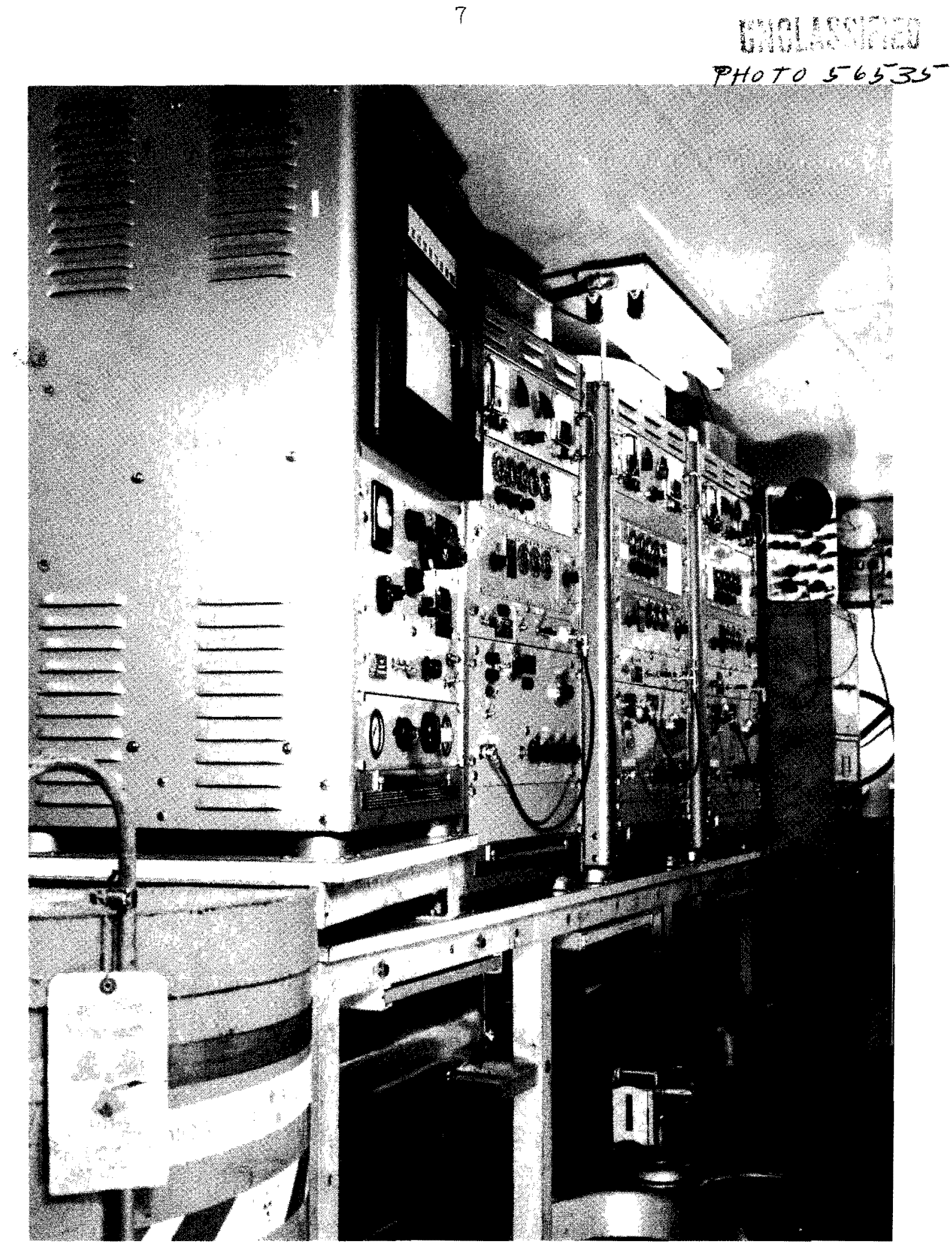

Fig. 5. Interior of the Mobile Radiation Detection Laboratory. This picture shows the instrumentation on the left side. 
etc., required to make the laboratory completely self sufficient. Instrumentation and the high sensitivity detector heads are designed to be interchangeable, although for the sake of convenience certain detectors are usually used with particular sets of electronics.

The practicality and durability of the entire design was demonstrated during the present study. The roughly 550 miles from Oak Ridge to Urbana was covered in about 20 hours of driving time, and the instruments were in excellent condition on arrival. Operation began as soon as the electronics had warmed to a stable temperature. During the week of operation at Urbana only one small segment of the instrumentation in a single rack threatened to give trouble, and since only four detector-instrument combinations were then being used, a quick interchange with the duplicate system of an unused rack permitted operation to continue without interruption.

Although generally somewhat modified and improved, the electronic instrumentation of the laboratory is basically standard. The detectors, however, have been specially designed and constructed for detection of extremely low levels of radiation. In the present study three types of detector were used. Thermal-neutron fluxes were observed with a high pressure $\mathrm{BF}_{3}$ proportional counter in which the $\mathrm{BF}_{3}$ gas, enriched to $96 \%$ in $\mathrm{B}^{10}$, is contained at a pressure of $76 \mathrm{~cm}$ of $\mathrm{Hg}$. Such a pressure, several times that conventionally used, increases sensitivity and aids in protecting the instrument against accidental damage. The sensitivity of this instrument is of the order of 7,400 counts $\cdot \min ^{-1} \cdot \mathrm{mrad}^{-1} \cdot \mathrm{hr}$.

Fast-neutron dose rates were measured with a modified long counter. In this counter a $\mathrm{BF}_{3}$ chamber identical to that described above is 
surrounded by a cadmium-covered polyethylene cylinder 8 in. in dia and 12-in. long. The polyethylene thickness at the end is adjusted to produce a response proportional to the dose in tissue. The sensitivity of the modified long counter is about 7,800 counts $\cdot \mathrm{min}^{-1} \cdot \mathrm{mrad}^{-1} \cdot \mathrm{hr}$.

All gamma-ray dose rate measurements in this study were made with an anthracene scintillation detector in which the sensitive element consists of a l-in.-dia, 1/2-in.-thick anthracene crystal. A thin aluminumcoated Mylar reflecting foil covers the forward face and the sides of the crystal but leaves the rear face bare. The whole is encased in 3-rnmthick Lucite so that the electron density in the crystal is characteristic of a large body in the gamma field. Thus it produces electrons and scatters electrons back into the crystal. The Lucite at the rear face also serves as a light piper connecting the crystal to the window of an RCA 6655 photomultiplier tube. A 5-mil-thick aluminum case serves as a light shield and to some extent protects the crystal from mechanical damage. A special pulse counting technique developed for use with this dosimeter is made practical by employment of a novel transistorized integrator.? Tissue dose rates as low as $0.02-0.03 \mathrm{mrad} / \mathrm{hr}$ or as high as $\sim 20 \mathrm{mrad} / \mathrm{hr}$ can be accurately measured with this instmument.

\section{EXPERIMENTAL PROCEDURE}

Prior to the arrival of the ORNL equipment at Urbana, Mr. Gerald P. Beck, the reactor supervisor, had established a two-foot-square grid on

2. Designed by P. T. Perdue, ORINL Instmumentation and Controls Division. A detailed report covering the design and use of this device is in preparation. 
all faces of the reactor shield. All shield measurements were referred to this grid, and since the grid system utilized the beam hole center lines as origins of coordinates, all positions are permanently reproducible. A similar grid was generally used to control measurements upon the horizontal surfaces, except for the region directly above the reactor tank. In this region it was more convenient to relate the data to the square opening in the top shield. Normally a single one-minute count was taken at all grid intersections with each detector, with duplicate counts taken only when the first count was suspect. An extremely valuable feature of the mobile laboratory lies in the habitual use of sound-powered telephones to maintain constant communication between the operator handling the detector and his counterpart manning the scaler equipment. The count rate being detected is continuously heard as clicks in the headsets of both men and thus each has an instant knowledge of the intensity of the field being examined. Provision is made for scaling the count rate by factors of $10,10^{2}$, and $10^{3}$ to cover a wide range of radiation levels. After a count was made at a grid location the detector was slowly swept over the shield surface between locations, and since the count rate was continuously audible to the detector operation, any small region of unusual intensity was immediately found, located with respect to the coordinate grid, and a one-minute count obtained. This practice insured rapid progress, while guaranteeing that no region of activity would escape observation.

In addition to the general examination of the shield leakage, several additional investigations were made. These included fast-neutron flux measurements made within a beam port at a steady-state power of $1 \mathrm{kw}$, 
and again during a pulse generated by the insertion of approximately two dollars of reactivity. The streaming from each of the beam holes at various power levels was also measured.

\section{RESULTS}

Fluxes and Dose Rates at Beam Ports

The chronologically first data obtained during this study were a series of measurements of thermal-neutron flux and fast-neutron dose rates at the ports of the four beam holes penetrating the shield. These beam holes are diagrammed in Fig. 6. The data are of interest from a safety standpoint, since the use of the holes for irradiations or for experiments involving radiation beams may require special precautions. Initially a few measurements were made with the reactor shut down, then reactor power was increased to 1 watt for a second set and to 5 watts for a third set. Three one-minute counts were made at each port, and an arithmetic average is reported. The data are shown in Table 1. A gammaray dosimeter was also positioned during these measurements, but the flux from the holes was generally sufficient to saturate the sensitive

crystals (the level at which this occurs is $\sim 3 \times 10^{5} \mathrm{cpm}$ ) and make the results meaningless in most cases. The few gamma-ray dose rates we believe accurate are also show in Table 1.

Threshold Foil Measurements

It was noted above that one of the more interesting features of the TRIGA Mark II is its capability of being pulsed. In order to estimate the integrated dose at the shield face for a pulse, the neutron flux in the west beam hole about 6 in. from the core under steady-state l-kw operation was compared with the flux at the same location during a pulse. 


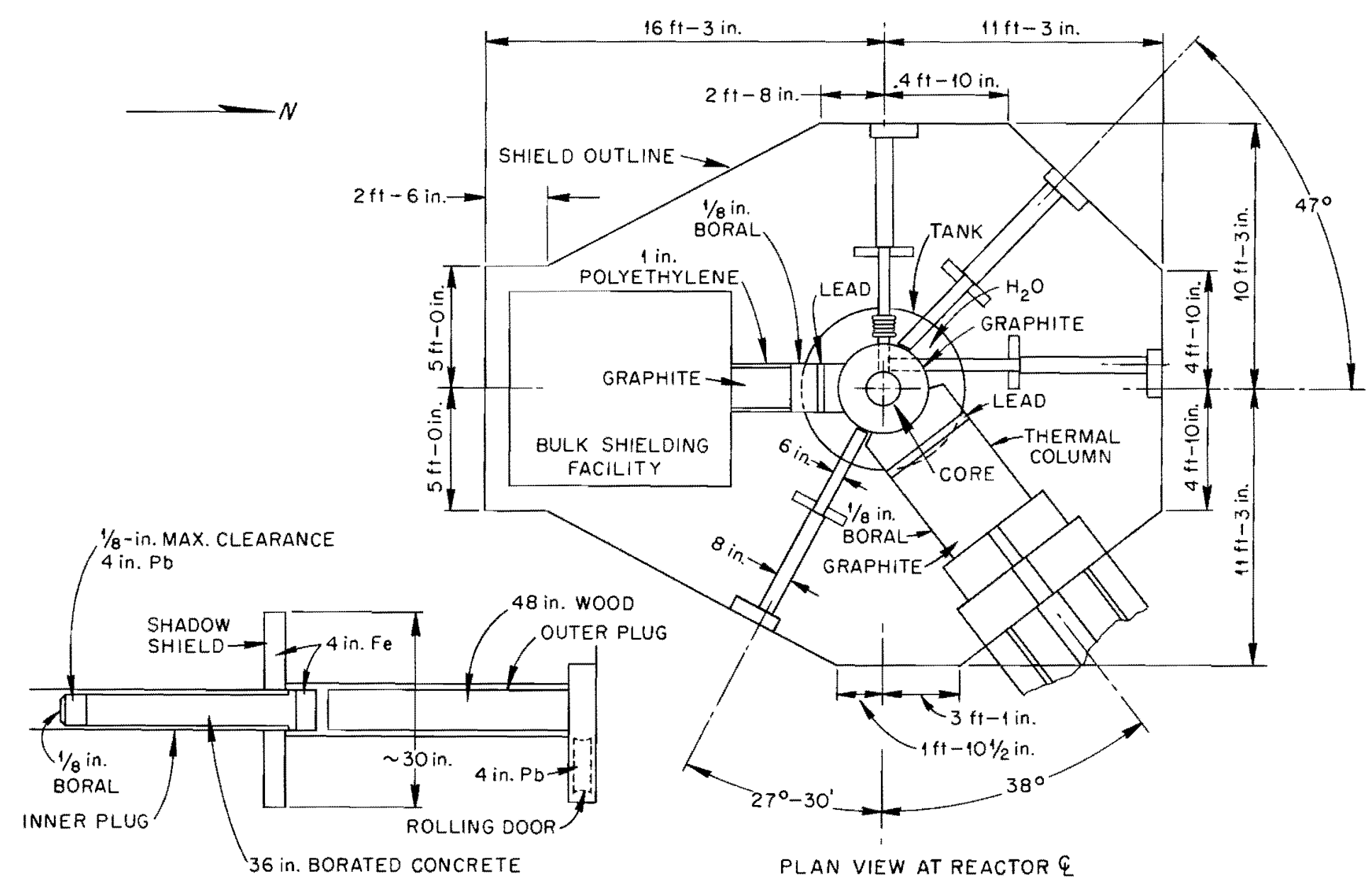

Fig. 6. Plan View of TRIGA Mark II Shield, Showing Beam Ports, Thermal Column, and Bulk Shielding Facility. 
Table 1. Fast-Neutron, Thermal-Neutron, and Gamma-Ray Measurements at the Beam Ports, for Three Reactor Power Levels

\begin{tabular}{|c|c|c|c|c|c|c|}
\hline $\begin{array}{c}\text { Type of } \\
\text { Measurement }\end{array}$ & North Port & $\begin{array}{l}\text { Northwest Port } \\
\text { (Graphite in } \\
\text { West Port) }\end{array}$ & $\begin{array}{l}\text { Northwest Port } \\
\text { (No Graphite in } \\
\text { West Port) }\end{array}$ & $\begin{array}{c}\text { West Port } \\
\text { (Graphite } \\
\text { In) }\end{array}$ & $\begin{array}{l}\text { West Port } \\
\text { (Graphite } \\
\text { Out) }\end{array}$ & $\begin{array}{l}\text { Southeast } \\
\text { Port }\end{array}$ \\
\hline \multicolumn{7}{|c|}{ Reactor at Zero Power } \\
\hline $\begin{array}{l}\text { Fast-Neutron Dose } \\
\text { Rate (mrad/hr) }\end{array}$ & $3.62 \times 10^{-4}$ & & & & & \\
\hline $\begin{array}{l}\text { Thermal-Neutron } \\
\text { Flux } \\
\left(\mathrm{n} \cdot \mathrm{cm}^{-2} \cdot \mathrm{sec}^{-1}\right)\end{array}$ & $6.59 \times 10^{-3}$ & & & & & $7.74 \times 10-3$ \\
\hline $\begin{array}{l}\text { Gamma-Ray Dose } \\
\text { Rate (mr/hr) }\end{array}$ & & & & $1.34 \times 10^{1}$ & $1.30 \times 10^{2}$ & \\
\hline \multicolumn{7}{|c|}{ Reactor at I w } \\
\hline $\begin{array}{l}\text { Fast-Neutron Dose } \\
\text { Rate (mrad/hr) }\end{array}$ & $1.70 \times 10^{0}$ & $1.17 \times 10^{0}$ & $1.40 \times 10^{0}$ & $9.98 \times 10^{-1}$ & $1.56 \times 10^{1}$ & $9.08 \times 10^{0}$ \\
\hline $\begin{array}{l}\text { Thermal-Neutron } \\
\text { Flux } \\
\left(\mathrm{n} \cdot \mathrm{cm}^{-2} \cdot \mathrm{sec}^{-1}\right)\end{array}$ & $4.76 \times 10^{2}$ & $3.23 \times 10^{2}$ & $3.03 \times 10^{2}$ & $3.42 \times 10^{2}$ & $1.14 \times 10^{3}$ & $7.63 \times 10^{2}$ \\
\hline $\begin{array}{l}\text { Garma-Ray Dose } \\
\text { Rate }(\mathrm{mr} / \mathrm{hr})\end{array}$ & & & & $1.603 \times 10^{1}$ & & \\
\hline \multicolumn{7}{|c|}{ Reactor at $5 \mathrm{w}$} \\
\hline $\begin{array}{l}\text { Fast-Neutron Dose } \\
\text { Rate (mrad/hr) }\end{array}$ & $8.78 \times 10^{0}$ & $5.96 \times 10^{0}$ & $6.96 \times 10^{0}$ & $5.01 \times 10^{0}$ & $7.39 \times 10^{1}$ & $4.58 \times 10^{1}$ \\
\hline $\begin{array}{l}\text { Thermal-Neutron } \\
\text { Flux } \\
\left(\mathrm{n} \cdot \mathrm{cm}^{-2} \cdot \mathrm{sec}^{-1}\right)\end{array}$ & $2.29 \times 10^{3}$ & $1.61 \times 10^{3}$ & $1.52 \times 10^{3}$ & $1.63 \times 10^{3}$ & $5.32 \times 10^{3}$ & $3.96 \times 10^{3}$ \\
\hline
\end{tabular}


A threshold foil technique was chosen for the flux measurements because of its convenience and adaptability to the physical situation. Various applications of this technique have been reported; $3,4,5$ for convenience and exactness, however, an outline of the method is included as Appendix A.

The threshold foils used in this study are listed in Table 2.

Table 2. Threshold Detectors Used in Measurements of Flux in West Beam Hole; University of Illinois TRIGA Mark II Reactor

\begin{tabular}{llll}
\hline Detector & Reaction & $E_{\text {eff }}($ Mev $)$ & $\bar{\sigma}$ (barns) \\
\hline $\mathrm{Pu}^{239}$ & $(\mathrm{n}, \mathrm{f})$ & $0.001-0.002$ & 1.95 \\
$\mathrm{~Np}^{237}$ & $(\mathrm{n}, \mathrm{f})$ & 0.75 & $1.60 *$ \\
$\mathrm{U}^{238}$ & $(\mathrm{n}, \mathrm{f})$ & 1.50 & 0.55 \\
Sulfur & $\mathrm{S}^{32}(\mathrm{n}, \mathrm{p}) \mathrm{P}^{32}$ & 2.9 & $0.23^{* *}$ \\
\hline
\end{tabular}

* Based on recent cross section given by H. W. Schmitt and R. B. Murray, Phys. Rev. 116, 1575 (1959).

**Based on recent cross section given by L. Allen, Jr., et al., Phys. Rev. 107, 1363 (1957).

The operations involved in obtaining the foil data were essentially straightforward. The west beam hole was chosen because it looks directly at the reactor core. The inner or core end of this hole is closed by a graphite plug, which was removed so that the spectmum observed would have the least possible moderation. The threshold folls were packaged

3. J. B. Trice, et al., A Series of Thermal, Epithermal, and Fast-Neutron Measurements in the M. T.R., ORNL-CF-55-10-140 (1955).

4. G. S. Hurst, et al., Rev. Sei. Instr. 27, 153 (1956).

5 T. V. Blosser, et al., Fast-Neutron Flux Measurements in the ORNL Graphite Reactor shield, ORNL-CF-58-8-1 (1958). 
in a 1-cm-thick $\mathrm{B}_{4}^{10} \mathrm{C}$ spherical shell of density 1.23 which was itself encased in a stainless steel carrier which was positioned in the beam hole. The bare and cadmium-covered gold foils used to measure thermal and epithermal flux were placed in the carrier in the same plane with the threshold foils.

For the steady state mun the foils were exposed for one hour at a constant power of $1 \mathrm{kw}$. In the pulsed run foils were exposed to the flux from a nominal two-dollar pulse. It may be seen from Fig. 7 that this exposure included not only the "spike" of the $\sim 30 \mathrm{msec}$ pulse but also the relatively long decay of the pulse below about $6 \mathrm{Mw}$. The foils used for the two exposures were carefully matched both in weight and in impurity content. The time elapsing between exposure and counting of the induced activity was carefully measured by stop watches.

The activities induced in the fission foils were separately determined by gamma-ray counting using a $3-\times 3-i n$. NaI $(T /)$ crystal scintillation counter. The $\mathrm{P}^{32}$ beta decay of the sulfur foil was counted on the same device but using a Nuclear Enterprises, Ltd., NE 102 plastic scintillator as the detector.

The results of this portion of the study are shown in Table 3 . The variation observed in the ratio of the flux during the pulse to that during steady-state operation is not believed to be significant, and perhaps reflects the accumulated inaccuracy of the measuring process. From this data, however, we estimate that the fast-neutron flux from the TRIGA core during a nominal two-dollar pulse is approximately four times that of an hour's operation at $1 \mathrm{kw}$. 


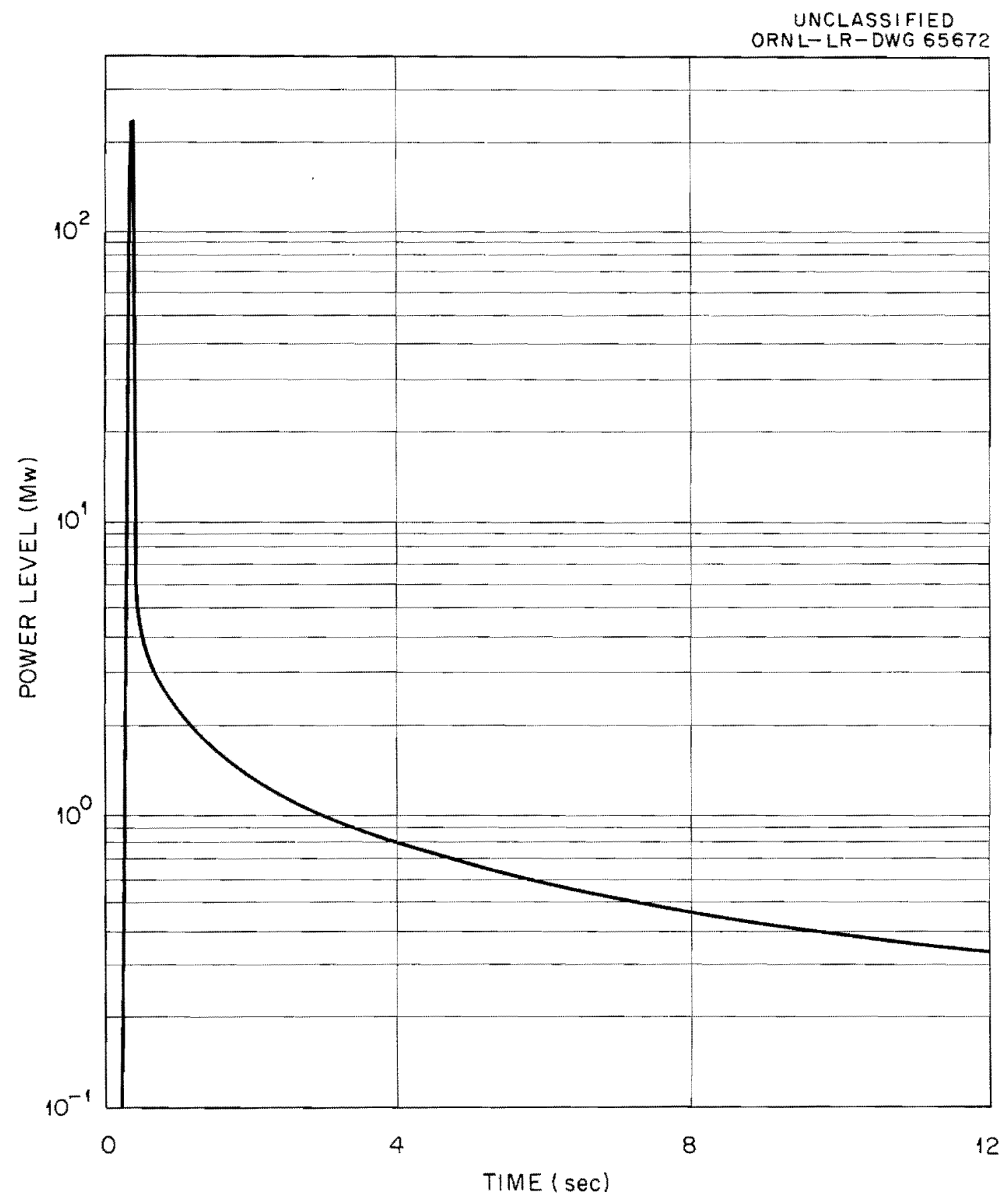

Fig. 7. Transient Power vs. Time for the TRIGA Mark II Reactor and a $\$ 2.00$ Pulse. (From NP-8299, Oct., 1959) 
The highest fast-neutron dose rate observed during the shield measurements later described occurred at the base of the door to the thermal column and was $\sim 9.6 \times 10^{-2} \mathrm{mrad} / \mathrm{hr}$ during reactor operation at a power level of $100 \mathrm{kw}$. A simple computation based on this value results in an estimate of $3.8 \times 10^{-3} \mathrm{mrad}$ for the maximum dose to be expected during a nominal two-dollar pulse.

\section{Table 3. Neutron Flux Measurements in West Beam Hole of University of IIIinois TRIGA Mark II Reactor Under Steady-State and Pulsed Conditions}

\begin{tabular}{|c|c|c|c|c|}
\hline \multirow[b]{2}{*}{$\begin{array}{l}\text { Neutron Energy } \\
\text { Group }\end{array}$} & \multicolumn{2}{|c|}{ Integrated Neutron Flux $\left(\mathrm{n} / \mathrm{cm}^{2}\right)$} & \multirow[b]{2}{*}{ Ratio: } & \multirow[b]{2}{*}{$\frac{\text { Pulse }}{\text { Steady State }}$} \\
\hline & $\begin{array}{l}\text { Steady State: } \\
1 \mathrm{hr} \text { at } 1 \mathrm{kw}\end{array}$ & $\begin{array}{c}\text { Duration of Nominal } \\
\$ 2.00 \text { Pulse }\end{array}$ & & \\
\hline Thermal* & $1.59 \times 10^{13}$ & $6.19 \times 10^{13}$ & & 3.89 \\
\hline Epithermal* & $4.18 \times 10^{12}$ & $1.63 \times 10^{13}$ & & 3.90 \\
\hline $1-2 \mathrm{kev}--0.75 \mathrm{Mev}$ & $5.2 \times 10^{12}$ & $2.52 \times 10^{13}$ & & 4.85 \\
\hline $0.75-1.50 \mathrm{Mev}$ & $7.00 \times 10^{12}$ & $3.07 \times 10^{13}$ & & 4.39 \\
\hline $1.50--2.90 \mathrm{Mev}$ & $3.51 \times 10^{12}$ & $1.49 \times 10^{13}$ & & 4.25 \\
\hline $2.90 \mathrm{Mev}--\infty$ & $1.49 \times 10^{12}$ & $5.95 \times 10^{12}$ & & 4.00 \\
\hline
\end{tabular}

* Measured with bare and cadmium-covered gold foils.

From the data it is also possible to compute the total fast-neutron first-collision tissue dose at the point in the beam hole where the foils were exposed. The relation is 4

$$
\begin{aligned}
D(\text { rads })= & {\left[0.95\left(N_{P u}-N_{N p}\right)+2.4\left(N_{n p}-N_{u}\right)+\right.} \\
& \left.3.0\left(N_{u}-N_{s}\right)+3.7 N_{s}\right] \times 10^{-9}
\end{aligned}
$$


where

$N_{i}=$ number of neutrons $/ \mathrm{cm}^{2}$ above the element energy threshold.

According to $\mathrm{Eq}$. (1), a total dose of $3.78 \times 10^{4}$ rads was accumulated during the $1-\mathrm{hr}$ exposure at one $\mathrm{kw}$, and $1.64 \times 10^{5}$ rads during the nominal two-dollar pulse.

From the data of Table 3 a rough approximation of part of the neutron spectrum of the TRIGA Mark II core may be obtained. Such a spectrum is plotted in Fig. 8 and is compared in shape to the fission spectrum given by Cranberg, et al. ${ }^{6}$ As might be expected, the TRIGA spectrum peaks at a lower energy than does the fission spectrum.

Shield Measurements

The major portion of this study was concerned with a detailed examination of the thermal-neutron flux and the fast-neutron and gamma-ray dose rates at the surface of the shield. The results are presented as Figs. 9 through 11 in which the shield surfaces have been developed or "unwrapped" to lie flat upon the page. Thermal-neutron fluxes are presented in Fig. 9, fast-neutron dose rates in Fig. 10, and gamma-ray dose rates in Fig. 11. Perhaps the most noticeable feature of the shield data is the extremely low leakage rates prevailing over the surface of the shield. In some locations an apparent contradiction may even be noted, in which the reported dose rate is less than the average background. This is due to the statistical fluctuation involved in very low counting rates and probably to the shielding of cosmic rays by the concrete itself.

6. L. Cranberg, et a1., Phys. Rev. 103, 662 (1956). 


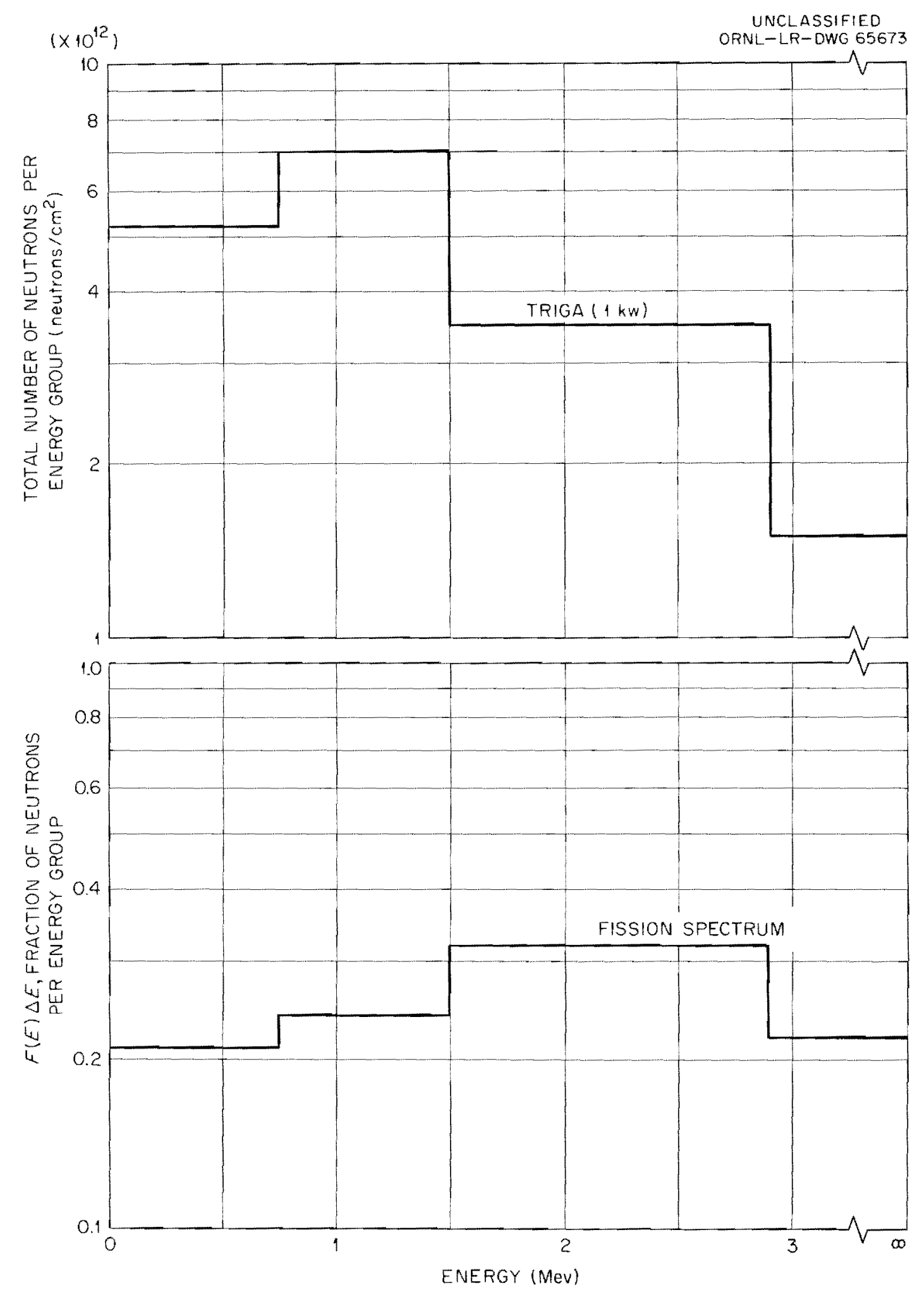

Fig. 8. Comparison of Fission Spectrum with Observed Neutron Spectrum of TRIGA Mark II. 
UNCLASSIFED
ORNLLLP-OWÉ 64553

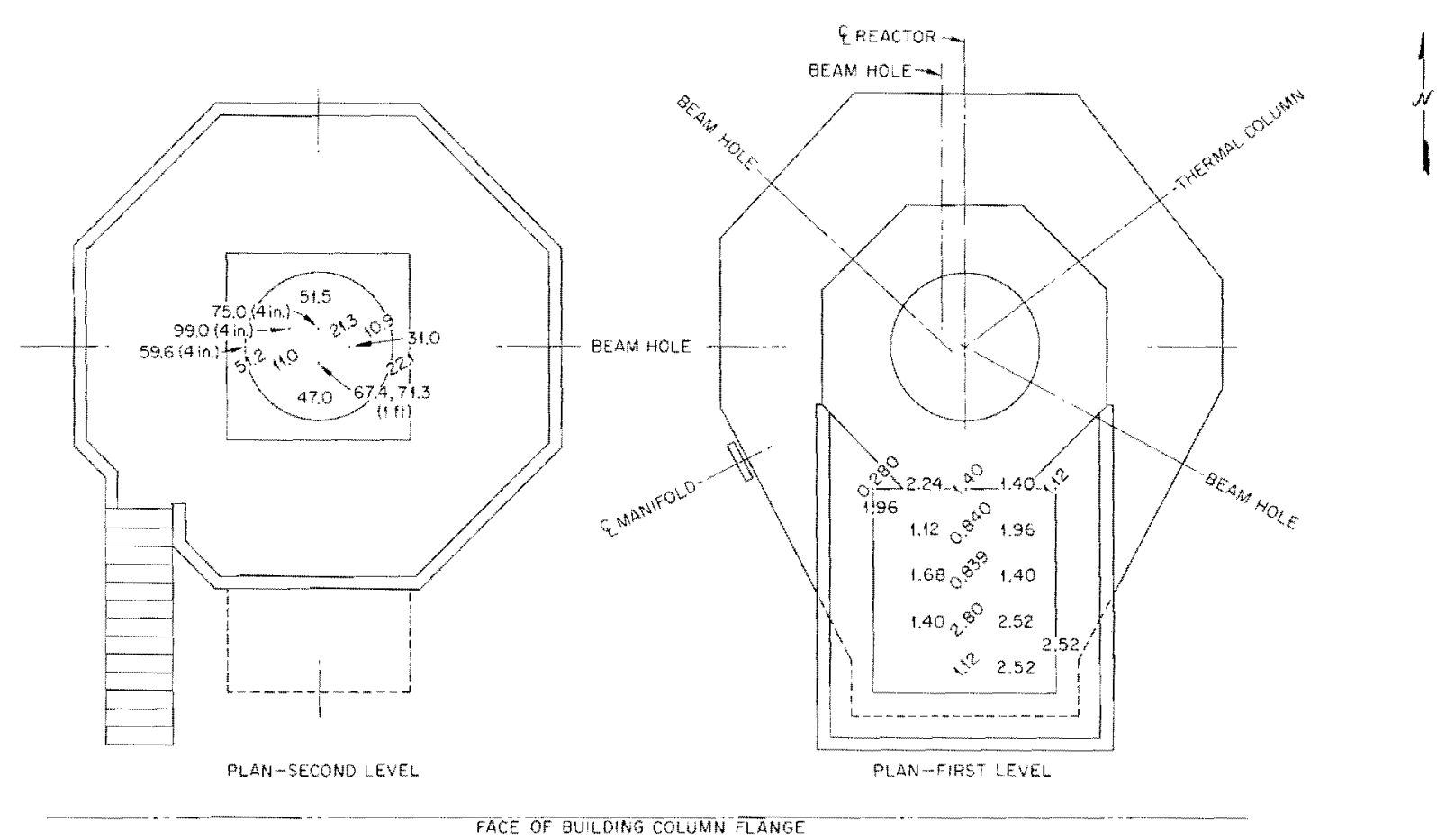

\begin{tabular}{|c|c|c|c|c|c|c|c|c|c|}
\hline$s$ & $S E$ & $\varepsilon$ & $\mathrm{NE}$ & & & $N W$ & w & $5 w$ & 5 \\
\hline 1.44 & $1.14 \quad 4.67$ & $1.95+.95$ & 1.39 & 4.11 & 2.79 & 0.836 & 0.836 & 2.23 & 0.836 \\
\hline 279 & 0.836 & $1.39 \quad 1.67 \quad 1.41$ & 139 & & & 2.79 & 1.11 & 1.95 & \\
\hline 1.39 & $\begin{array}{l}1.39 \quad 1.67\end{array}$ & 1.112 .59390 & $2,23 \quad 1.95$ & 1.39 & 2.23 & $1.95 \quad 1.6 ?$ & $0.836 \quad 1.39$ & $1.6 ?$ & 1.39 \\
\hline 39 & 2.23 & 2.79 & 4.18 & & & $2.5 !$ & 0.836 & 1.39 & \\
\hline
\end{tabular}

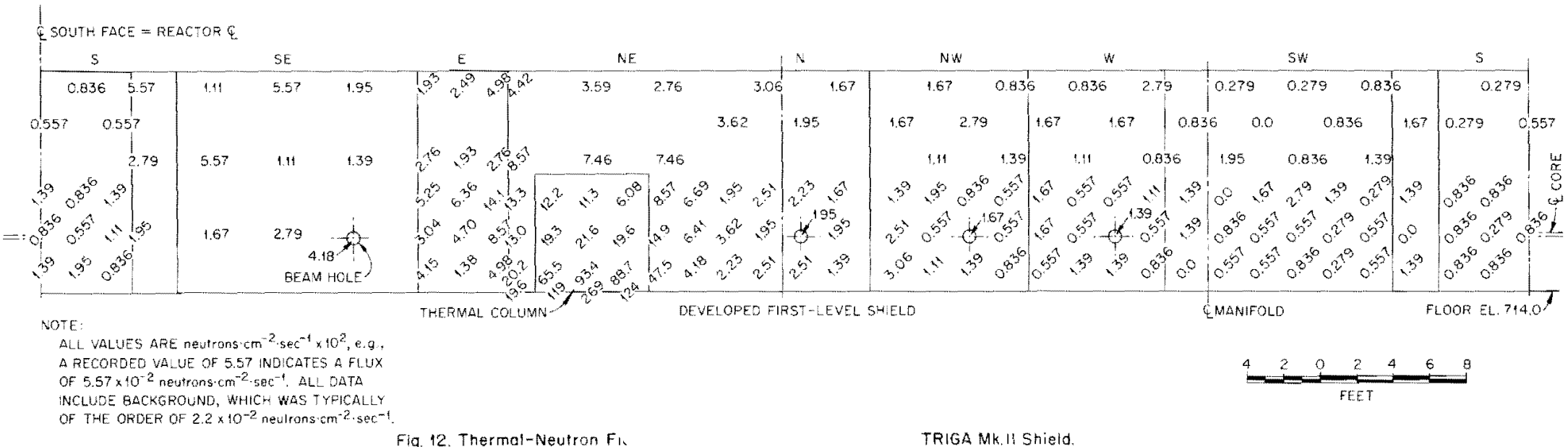

Fig. 9. Thermal-Neutron Fluxes at Surface of University of Illinois TRIGA Mark II Shield. 

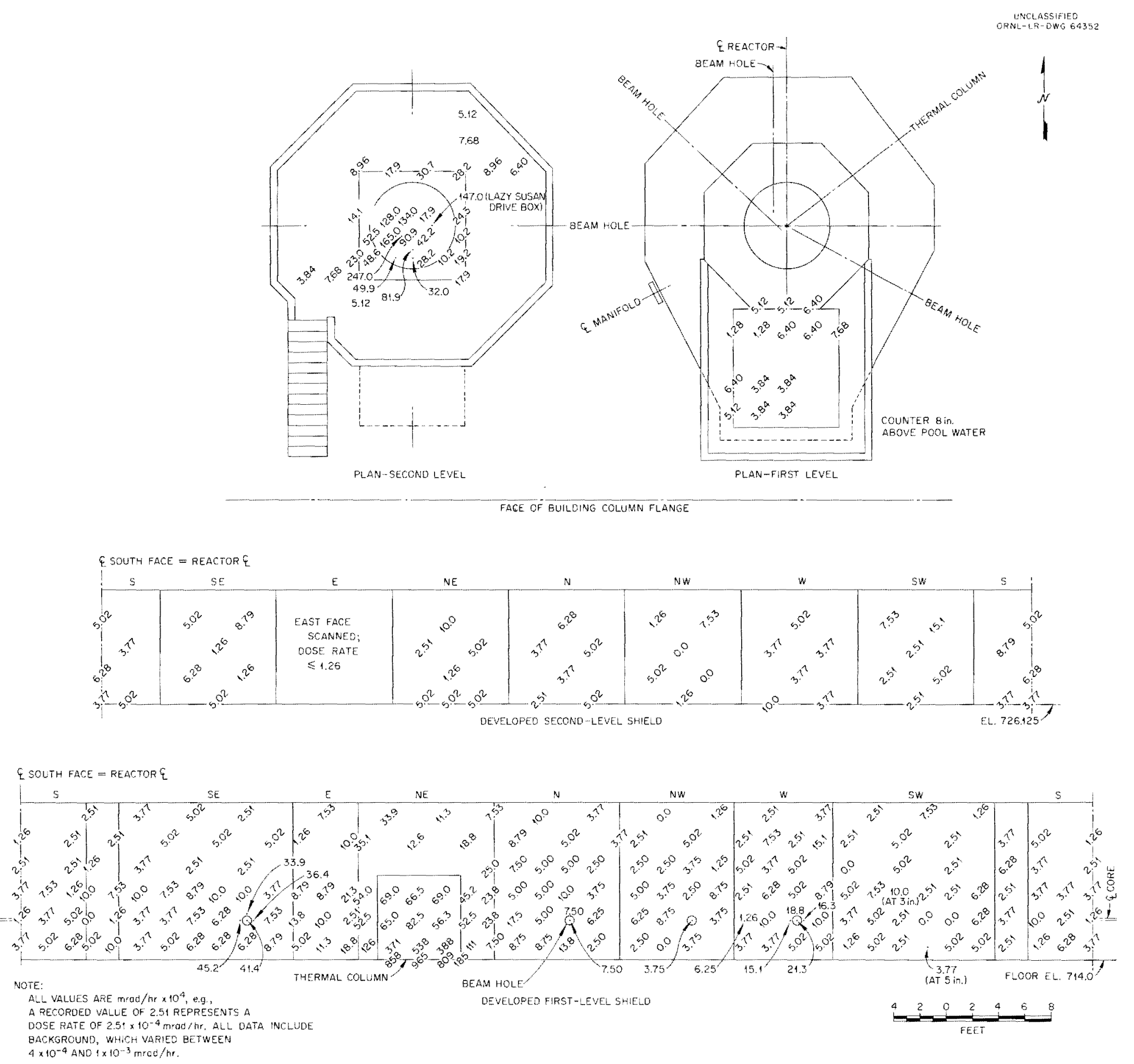

Fig. 10. Fast-Neutron Dose Rates at Surface of University of Illinois TRIGA Mark II Shield. 

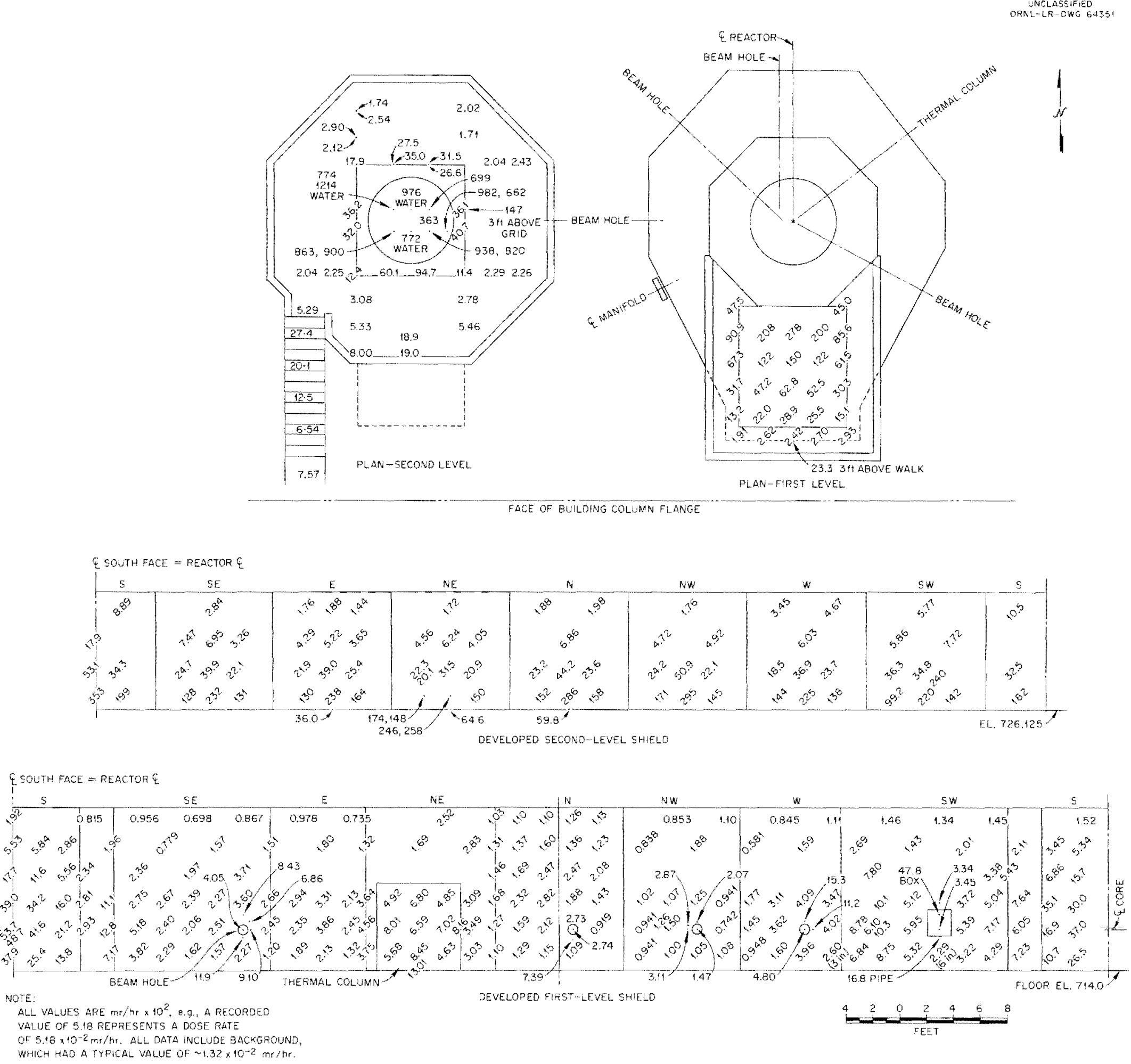

Fig. 11. Gamma-Ray Dose Rates at Surface of University of IIIinois TRIGA Mark II Shield. 
The maximum shield leakage rates for fast and thermal neutrons were observed at the base of the access door to the thermal column, but were very low. The fast-neutron dose rate at this location, during operation of the reactor at $100 \mathrm{kw}$, was $9.65 \times 10^{-2} \mathrm{mrad} / \mathrm{hr}$, the gamma-ray dose rate but $1.3 \times 10^{-1} \mathrm{mr} / \mathrm{hr}$, and the thermal-neutron flux $2.69 \mathrm{n} \cdot \mathrm{cm}^{-2} \cdot \mathrm{sec}^{-1}$. In the case of the gamma-ray dose rate, somewhat higher rates were noted at a few points directly above the water surface of the reactor pool, a typical value being $9.76 \mathrm{mr} / \mathrm{hr}$. Detailed examination of the beam hole plugs showed them to be extremely effective in preventing any observable streaming around their edges.

\section{Ventilation System Eilter Examination}

Reactor-room air and gases generated within the reactor thermal column and beam ports are made to pass through a filter system, sketched in Fig. 12, before being vented to the outside atmosphere through a 60 -fthigh stack. A few gamm-ray dose rate measurements made at appropriate locations on the filter system showed activities ranging from a low of $1.44 \times 10^{-2} \mathrm{mr} / \mathrm{hr}$ to a high of $3.87 \times 10^{-2} \mathrm{mr} / \mathrm{hr}$, the latter on the prefilter section of the ventilation system.

No examination of the stack air was made.

\section{ERRORS}

The adoption of a fixed counting time of one minute for the measurements of this study makes impossible an assignment of an over-all statistical error for the data. At the regions of lowest count rate fastneutron counts fell as low as one per minute, and the highest count rate observed anywhere on the shield was only $772 \mathrm{cpm}$. The statistical error thus ranged from $\pm 100 \%$ to about $\pm 4 \%$ at best. A similar situation 


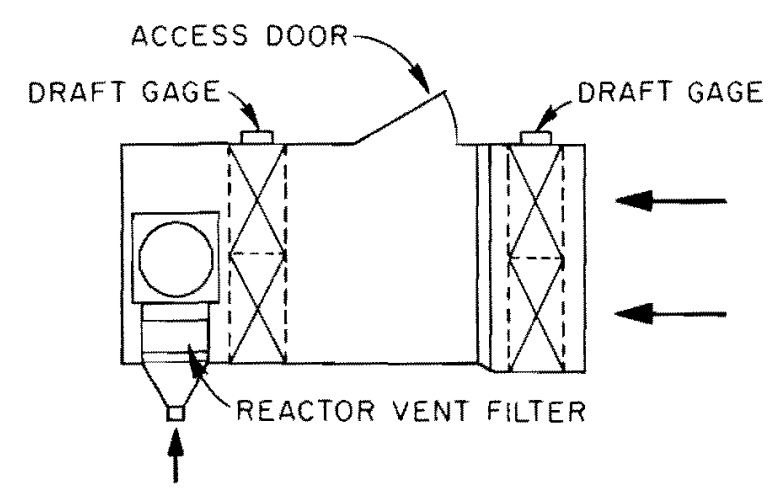

SECTION A-A

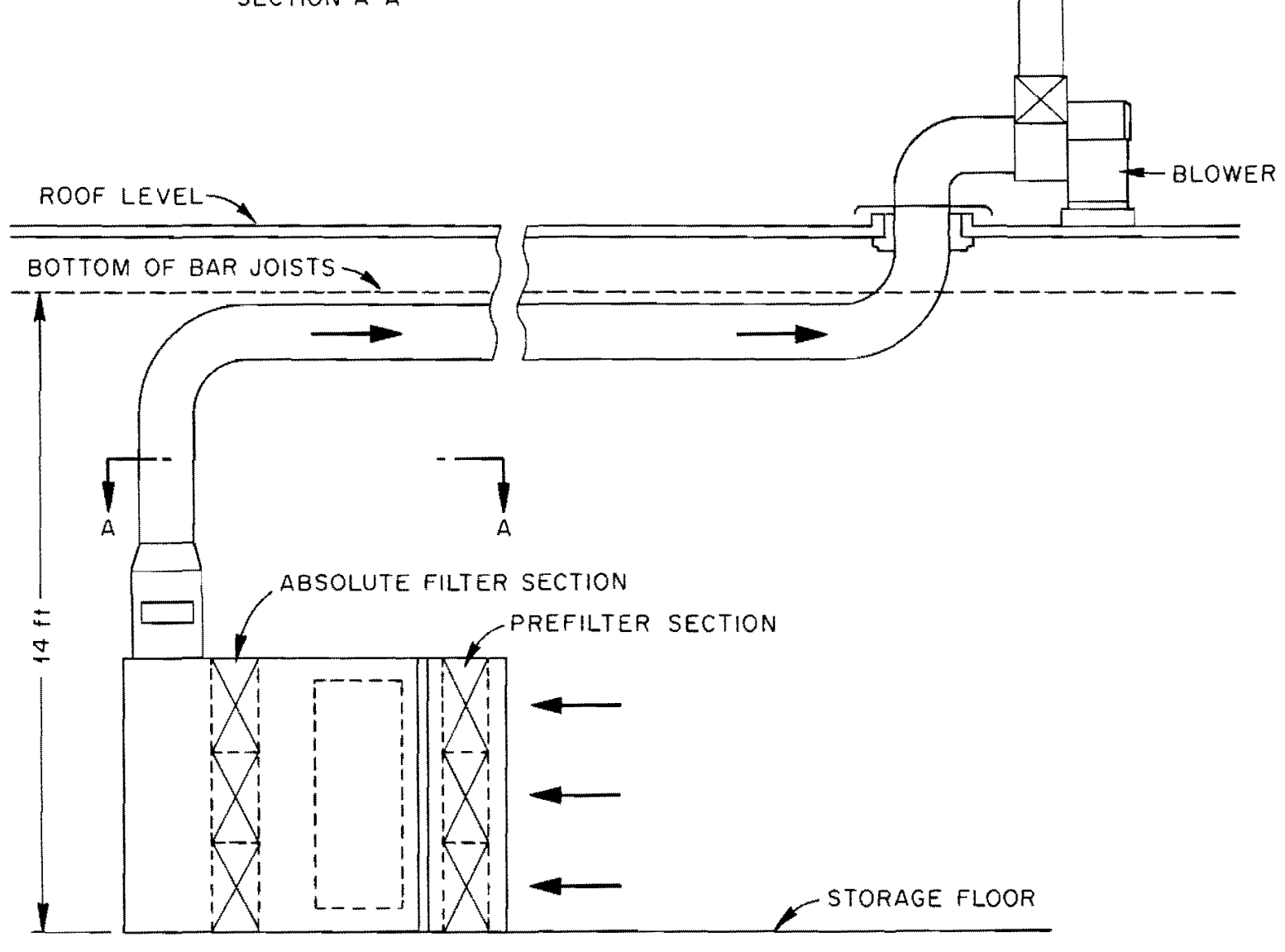

Fig. 12. Diagram of the University of Illinois TRIGA Mark II Ventilation System. 
prevailed for thermal-neutron counting; gamma-ray counts were, however, much better in a statistical sense. For the gamma-ray data counting errors are estimated to range from $\pm 10 \%$ to $\pm 0.5 \%$. It is obvious, of course, that as the importance of any measurement increased, in the sense of increased dose rate, so did its statistical accuracy.

The thermal- and fast-neutron detectors are believed to have an inherent error of $< \pm 6 \%$ at $I \mathrm{mrem} / \mathrm{hr}$, based upon previous calibrations. The calibrations of the garma-ray detector indicate that an error of $\pm 10 \%$ is conservative. We therefore conclude that for the instrumental data an error of $\pm 8 \%$ may be safely assumed for the significant fast- and thermal-neutron values. For the garma-ray data we assume a conservative error of $\pm 12 \%$.

The accuracy of the foil data is based, in the limit, upon the precision with which cross sections are presently known. The currently quoted error in the $2200 \mathrm{~m} / \mathrm{sec}$ activation cross section for gold is $\pm 10 \%$, the most recent fission cross section for $\mathrm{Np}^{237}$ has an estimated uncertainty of $\pm 7 \%$, and so on. Calibration errors for the foil counter used are roughly $\pm 5 \%$; counting statistics contribute $\pm 3 \%$. A combined error of $\pm 12 \%$ would seem reasonable for the foil data.

\section{CONCLUSIONS}

The examination of the University of Illinois TRIGA Mark II shield Indicated that the shield is a sound, tight structure without any areas or zones of significant leakage. Beam port plugs were effective in permitting no radiation streaming. Even during the pulse condition no apparent hazard to personnel appears to exist at any point on the shield surface or within the reactor room. 


\section{ACKNOWLEDGEMENTS}

The rapid completion of this study was due in large measure to the wholehearted cooperation of a large group of volunteer assistants, all of whom ignored position and personal convenience to expedite this work. of the reactor staff, Mr. G. P. Beck, the reactor supervisor; P. R. Hesselmann, the health physicist assigned to the reactor; and R. L. Harrison were especially energetic and cooperative, on occasion working well into the night hours as the study required. Special thanks are due to faculty members M. E. Wyman, Professor of Physics and Nuclear Engineering; D. F. Hang, Associate Professor of Electrical Engineering; and G. H. Miley, Assistant Professor of Nuclear Engineering. No task was too arduous or too menial for this group.

Among the graduate students who assisted in the study, three officers of the Student Detachment, Hq. Fifth Army, Chicago, Illinois, were especially helpful and interested. They were J. R. Strickland, Capt., C. E.; Gerald W. Chase, Ist Lt., C. E.; and John Burt, Ist Lt., C. E. Other students participating in the work were Nelson Demuth; Alan Baxter, a Canadian; Bong Kown of Korea; Kodat1 Subra Rao from India; Carl Skygge of Sweden; and Mohammed Qaadri from Pakistan.

A representative of the USAEC, Mr. W. E. Twaler of the Chicago Compliance Area, was also present and assisted during part of the study. 


\section{APPENDIX A. THRESHOID FOILS}

The technique of neutron-flux measurement by threshold foils ${ }^{1}$ used in obtaining some of the data reported above is neither novel nor original to the present study. However, since the references quoted in the body of the text may be incomplete or difficult of access, it is believed that an outline of the principles and method may be of value.

The principle of the foil method is based upon the existence, for many elements, of specific nuclear reactions induced by neutrons. The occurrence of these reactions within a material which has been exposed to a neutron flux can be detected by observing the garma-ray or betaparticle emission in the decay of the unstable reaction product. Such activity can be represented by

$$
A \infty N \int_{0}^{\infty} \phi(E) \sigma_{i}(E) d E
$$

where

$$
\begin{aligned}
N= & \text { number of nuclei per } \mathrm{cm}^{3}, \\
\phi(E)= & \text { neutron flux, } \mathrm{n} \cdot \mathrm{cm}^{-2} \cdot \mathrm{sec}^{-1}, \text { of energy } E \text { to } E+\partial E, \\
\sigma_{i}(E)= & \text { microscopic cross section, in barns, for the ith type of } \\
& \text { process. }
\end{aligned}
$$

An ideal material for a threshold foll detector would be one such that its cross section was zero below a given threshold energy and constant for all energies above threshold and thus a step function. Although

1. A "foll" may indeed be a metal foil, or may as well be in powder or liquid form. 
such materials do not exist in nature, a number of elements have cross sections which approach this behavior. Examples are the fast-fission cross sections of $\mathrm{Np}^{237}, \mathrm{U}^{238}, \mathrm{Pu}^{239}$; and the $\mathrm{s}^{32}(\mathrm{n}, \mathrm{p}) \mathrm{P}^{32}, \mathrm{Al}^{27}(\mathrm{n}, \mathrm{p}) \mathrm{Mg}^{27}$, $\mathrm{AI}^{27}(\mathrm{n}, \alpha) \mathrm{Na}^{24}$, and $\mathrm{Mg}^{24}(\mathrm{n}, \mathrm{p}) \mathrm{Na}^{24}$ reaction cross sections. In the use of these materials as neutron detectors, the "true" threshold energy $\mathrm{E}_{\mathrm{T}}$ is obtained by extrapolation of the low-energy portion of the actual cross section to zero on a linear plot. An average cross section, $\bar{\sigma}$, is then chosen as a constant fitting the average of the actual data over the flat portion just following the initial rise region. Finally an effective energy threshold, $E_{\text {eff }}$, is determined by fitting a vertical line at an energy such that the excluded area under the tmue cross section curve is just equal to the area artificially introduced by the assumed step function. The process is diagrammed in Fig. A-I.

Proportionality 1 can now be rewritten as

$$
A \infty N \bar{\sigma} \int_{E_{\text {eff }}}^{\infty} \phi(E) d E
$$

which declares that the induced activity is proportional to the integrated neutron flux above the effective threshold, $\mathrm{E}_{\text {eff }}$.

In the practical application of the threshold foil technique, thin disks of $\mathrm{Np}^{237}, \mathrm{U}^{238}, \mathrm{Pu}^{239}$, aluminum, and magnesium, and thicker plaques of sulfur are carefully weighed, tested for chemical purity, and packaged within a $\mathrm{B}_{4}^{10} \mathrm{C}$ spherical shell. The purpose of the $\mathrm{B}^{10}$, of course, is to reduce the thermal-neutron activation of the foils. The package is exactly located within the neutron flux to be measured, and exposed for a time interval calculated to result in gamma or beta activities falling within the working limits of the scintillation counter to be used. 
UNCLASSIFIEO

ORNL-LR-DWG 66790

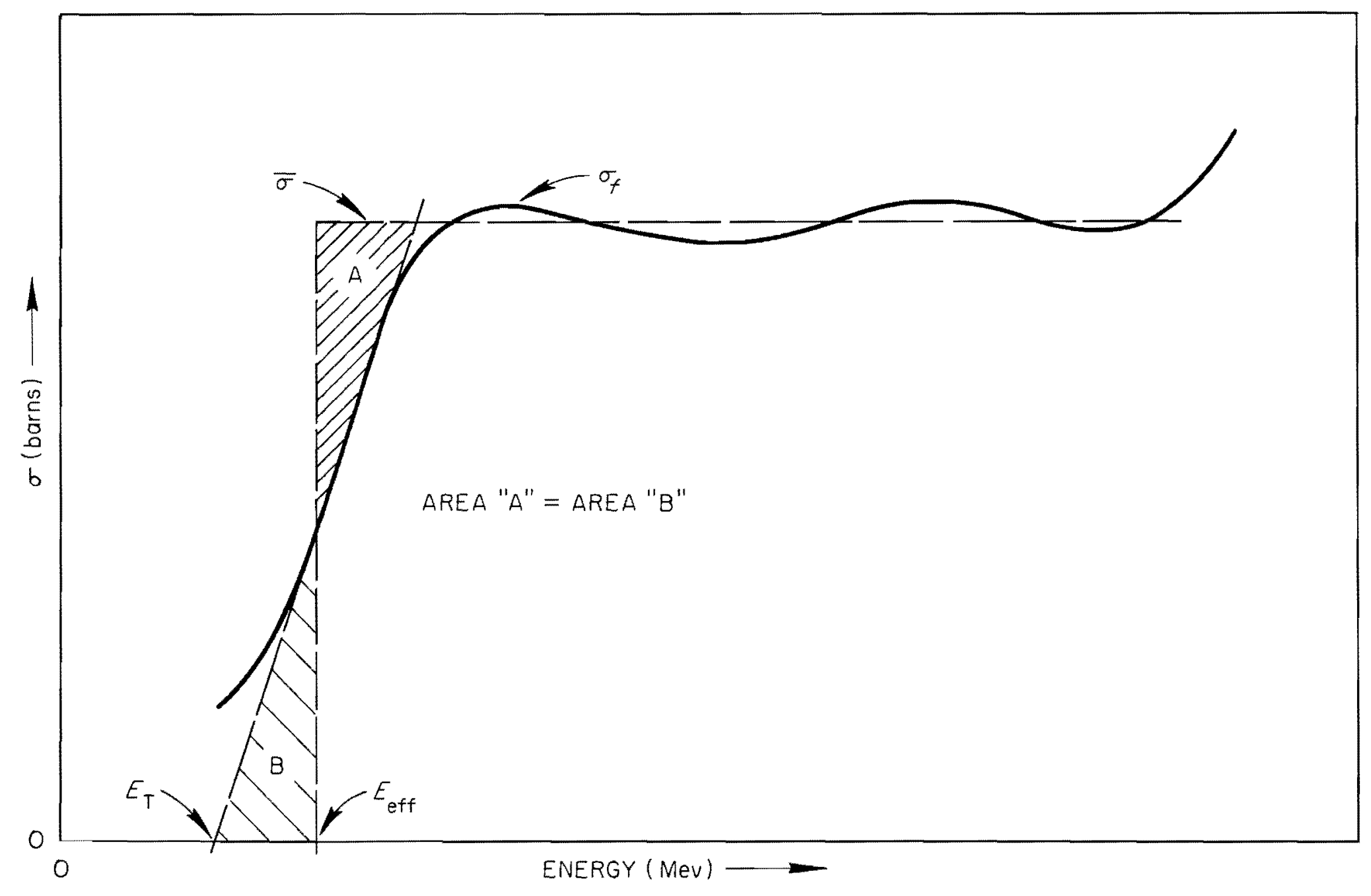

Fig. A-1. Idealized Cross Section, Showing Method of Determining $E_{T}$, $E_{\text {eff }}$, and $\bar{\sigma}$. 
The resulting activities, counted with appropriate crystals in a scintillation counter, are analyzed according to (A-2), giving values of the total flux of neutrons of energies above the various threshold energies. These data can then be utilized in various ways, viz., for the construction of crude spectra, for the calculation of dose, etc. 


\section{DISTRIBUTION}

\section{Internal}

1. E. P. Blizard

2-7. T. V. Blosser

8. A. D. Callihan

9-14. R. M. Freestone

15. L. B. Holland

16. W. H. Jordan

17. F. C. Malenschein

18. J. M. Miller

19. F. J. Muckenthaler

20. A. M. Weinberg

21-22. Central Research Library

23. Document Reference Library

24-33. Laboratory Records

\section{External}

34. C. K. Beck, Chief, Reactor Hazard Evaluation Branch, U. S. Atomic Energy Commission, Division of Civilian Application, Washington, D. C.

35-36. C. E. Clifford, General Atomic Division, General Dynamics Corp., San Diego 12, California.

37. Marshall S. Little, Radiological Health Consultant, Region III, U.S.P.H.S., 700 E. Jefferson Street, Charlottesville, Virginia.

38. Peter A. Morris, Chief, Reactor Inspection Branch, U. S. Atomic Energy Commission, Division of Compliance, Washington, D. C.

39. H. M. Roth, U. S. Atomic Energy Commission, Oak Ridge Operations, Oak Ridge, Tennessee.

40. U. S. Atomic Energy Cormission, Division of Licensing and Regulation, Washington, D. C.

41-43. John F. Wett, Jr., U. S. Atomic Energy Commission, Division of Compliance, Washington, D. C.

44-49. Dr. Marvin E. Wyman, Professor of Physics and of Nuclear Engineering, University of Illinois, Urbana, Illinots.

50-64. Diviston of Technical Information Extension, Oak Ridge, Tennessee. 


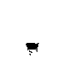

,

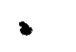

i

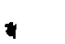

